\title{
МЕЖДУНАРОДНЫЕ ИСТОЧНИКИ ПРАВОВОГО РЕГУЛИРОВАНИЯ СОБЛЮДЕНИЯ ПРАВ ИНВАЛИДОВ, ОСУЖДЕННЫХ К ЛИШЕНИЮ СВОБОДЫ
}

\author{
(c) 2019 Аверьянова Ольга Владимировна \\ доцент кафедры финансового права \\ Санкт-Петербургский государственный экономический университет, Россия, Санкт-Петербург \\ E-mail: olin83@mail.ru
}

Причины и следствия инвалидности в разных странах различны. Данная разница объясняется тем, что объективно существуют разные социально-экономические условия стран и разные меры по обеспечению и содержанию осужденных инвалидов.

Система экономических социальных и правовых гарантий государства создающая инвалидам условия для преодоления и компенсации ограничений жизнедеятельности, а также создание им равных условий с другими гражданами является важной составляющей в процессе реализации социальной защиты инвалидов.

Основным элементом, положительно сказывающимся на социальной политике государства в отношении инвалидов и осужденных инвалидов, является законодательная база, основанная на международных принципах и отвечающая международным стандартам.

Правовая политика Российской Федерации на сегодняшний момент находится в переходном состоянии и существует необходимость дальнейшего усовершенствования данной области.

Ключевые слова: международное законодательство, права инвалидов, осужденные, социальные гарантии, право социального обеспечения, механизм правовой защиты.

Политика в отношении инвалидов на протяжении долгого времени претерпевала различные изменения. Изначально построенная только на помощи и уходе за инвалидами в специализированных учреждениях, законодательная база стала более совершенной и регулирует отношения с данной категорией лиц в образовательных, социальных, культурных учреждениях. Создаются различные фонды и общественные организации инвалидов и их семей, которые выступают за улучшение качества и условий жизни инвалидов в различных сферах.

Но при всей сложности решения определенных вопросов и проблем по изменению качества жизни, инвалидность не освобождает человека от уголовной ответственности. Наказание за совершенное преступление человек с ограниченными возможностями здоровья несет наравне с другими гражданами. Инвалидам предоставляются особые условия содержания в исправительных учреждениях в связи с определенными особенностями их здоровья. По состоянию на 1 января 2019 года в учреждениях уголовно-исполнительной системы отбывали наказания 20963 осужденных инвалида, что составляет 4\% от общего числа осужденных.

В Российской Федерации нарушение прав осужденных-инвалидов впервые было зафиксировано и установлено решением в феврале 2014 года Европейского суда по правам человека. Были зафиксированы и доказаны факты нарушения права не подвергаться пыткам или жестоким, бесчеловечным, унижающим достоинство видам обращения и наказанию [1].

K наиболее острым проблемам следует отнести: отказы в предоставлении медицинской помощи; несвоевременное и некачественное ее предоставление; отказы в направлении или несвоевременное направление лиц, нуждающихся в стационарной медицинской помощи, на медицинское обследование и лечение в лечебно-профилактические учреждения; отсутствие необходимых медикаментов; отсутствие необходимого медицинского оборудования; проблемы с обеспечением инвалидов протезно-ортопедической помощью; проблемы, связанные с признанием осужденного инвалидом и установлением группы инвалидности.

В постановлениях Европейского суда по правам человека неоднократно указывалось, что данная ситуация приводит к бесчеловечному или унижающему достоинство обращению с осужденными-инвалидами [5].

Инвалиды это одна из категорий наиболее 
социально-незащищенных осужденных. Их социальная адаптация, как в стенах исправительных учреждений, так и после освобождения из них, регламентируется целым комплексом правовых отраслей, а ее эффективность зависит от многих факторов, в том числе, правовых, экономических и организационных.

Неоказание надлежащей помощи или оказание ее в недостаточном объеме приводят к возникновению многочисленных жалоб и обращений от осужденных или их родственников в Европейский суд по правам человека.

Инвалид это лицо, которое имеет нарушение здоровья со стойким расстройством функций организма, обусловленное заболеваниями, последствиями травм или дефектами, приводящее к ограничению жизнедеятельности и вызывающее необходимость его социальной защиты.

Основным нормативным актом Российской Федерации в области государственной социальной политики в отношении инвалидов является Федеральный закон «О социальной защите инвалидов в Российской Федерации», принятый 24 ноября 1995 года и опубликованный в последующих изданиях. Он основан на Декларации о правах инвалидов, принятой Генеральной Ассамблеей ООН в 1975 году, и на правилах обеспечения равных возможностей для инвалидов, принятых Организацией Объединенных Наций в 1993 году.

В связи с изменениями, внесенными Распоряжением Правительства Российской Федерации от 23.09.2015 года № 1877-р в концепцию развития уголовной системы Российской Федерации до 2020 года, требуется обратить особое внимание на вопросы организации трудовой деятельности осужденных лиц с ограниченными возможностями в исправительных колониях. Данные изменения коснулись вопроса о гарантиях прав и законных интересов осужденных и задержанных. Особое внимание было уделено необходимости создания механизма правовой защиты осужденных с ограниченными возможностями.

Правила обеспечения равных возможностей для инвалидов были приняты Генеральной Ассамблеей Организации Объединенных Наций на ее сорок восьмой сессии 20 декабря 1993 года (резолюция 48/96) [4].

К числу важнейших законов, имеющих значение для социальной работы в уголовно-исполнительной системе с осужденными инвалидами, в первую очередь следует отнести Конвенцию ООН о правах инвалидов и Уголовно-исполнительный Кодекс РФ (далее - УИК РФ), в котором фиксируется в качестве задачи уголовноисполнительного законодательства РФ, наряду с другими, оказание помощи осужденным в социальной адаптации. Эта норма права имеет отношение ко всей массе осужденных, отбывающих уголовные наказания, в том числе к осужденным инвалидам.

В принятых правилах на первом Конгрессе Организации Объединенных Наций по предупреждению преступности и обращению с правонарушителями, состоявшемся в Женеве в 1955 году - «Минимальные стандартные правила обращения с заключенными», предусматривается, что «законодатель должен принять меры для обеспечения того, чтобы осужденные во время и после отбывания наказания сохраняли максимальные права в области социального обеспечения, социальных пособий и других гражданских интересов».

Во время отбывания наказания осужденными с ограниченными возможностями здоровья в исправительном учреждении должны сохраняться их максимальные права в сфере социального обеспечения, социальных льгот и иных гражданских интересов, а также после их освобождения. В Минимальных стандартных правилах обращения с заключенными, принятых в 1955 году, отмечается, что законодателю следует принять все меры для соблюдения данной нормы. Данное правило рекомендовано в основных международных документах. Кроме того, это является отражением принципов гуманизма и социальной справедливости в уголовном праве в части, касающейся социального обеспечения [3].

Важной задачей уголовно-исполнительного законодательства Российской Федерации является поддержка в сфере социального обеспечения: «помощь осужденным в социальной адаптации». Эта норма права распространяется на всех осужденных, включая лиц с ограниченными возможностями здоровья.

Ратификация Российской Федерацией Конвенции ООН о правах инвалидов распределила осуществление госпрограммы «Доступная среда» на пенитенциарные учреждения, что сказалось на эффективности исправления осужденных с ограниченными возможностями, улучшив психологический климат в подразделениях [2].

В связи с подписанием и ратификацией Кон- 
венции ООН о правах инвалидов и обращением к этой проблеме Уполномоченного по правам человека в Российской Федерации были дополнительно внесены необходимые изменения в Уголовно-исполнительный Кодекс РФ и Концепцию развития УИС РФ до 2020 г. Министру юстиции Российской Федерации направлены предложения Уполномоченного по созданию благоприятных условий и комфортной среды жизнеобеспечения для инвалидов и других лиц с ограниченными возможностями здоровья в учреждениях уголовно-исполнительной системы, подготовленные во исполнение Поручения Президента РФ (по итогам встречи с членами Совета при Президенте РФ по развитию гражданского общества и правам человека).

Внесены необходимые изменения в Концепцию развития уголовно-исполнительной системы РФ до 2020 г. Предусматривается разработка механизма правовой защиты осужденных инвалидов, а также содержащихся под стражей инвалидов; обеспечение оказания им медицинской помощи и создание улучшенных условий содержания и лицам, не способным или ограниченно способным обслуживать себя самостоятельно, в том числе техническими средствами, исходя из возможностей учреждений, осуществляющих надзор за осужденными.

Каждая страна имеет ряд положений, которые обеспечивают социальную помощь инвалидам и пожилым людям. В этих документах излагаются преимущества, которыми пользуются пожилые люди и инвалиды для получения социальной поддержки, описываются права пожилых людей на получение таких пособий и указываются пути их осуществления.

Следует отметить, что специализированные тюрьмы для инвалидов существуют только в Японии, их три. Специальным штатным сотрудникам поручен уход за нетрудоспособными преступниками. Тюрьмы оснащены подъемниками, специальными спусками для инвалидных кресел и поручнями в ванных и туалетах. Тюрьмы носят название «безбарьерных», однако в них сохраняются обычные ограничения.
Штатные сотрудники за инвалидами закреплены и в других странах. Например, в тюрьмах Великобритании, осужденный инвалид, нуждающийся в помощи, назначается лицу, которое ежедневно оказывает ему помощь в решении санитарных и гигиенических процедур, приеме пищи, передвижении (сотрудник по связи с инвалидами).

В некоторых странах существуют специальные правила обращения с осужденными инвалидами, которые отбывают наказание в местах лишения свободы. В соответствии с Уставом о защите осужденных с ограниченными возможностями инвалидность рассматривается как физическое или психическое расстройство, которое может включать проблемы со слухом и зрением, психическое заболевание и многие другие состояния. Осужденные с ограниченными возможностями должный иметь равный доступ с другими заключенными в столовую, зону отдыха, церковь, библиотеку.

В Соединенных Штатах Законом о реабилитации инвалидов установлена ответственность тюремных надзирателей, если они сознательно безразличны к серьезным медицинским потребностям заключенных-инвалидов.

Закон об американцах-инвалидах 1990 года: обеспечивает общую защиту гражданских прав инвалидов. Для молодежи, беременных женщин, инвалидов и других категорий граждан существуют отдельные программы и курсы, т.е. работа с ними ведется по индивидуальным программам. В тюрьмах и колониях обучение проводится в рамках программы «Планирование освобождения».

Одной из наиболее острых остается проблема создания необходимых условий доступности среды для маломобильных лиц в местах изоляции.

Общими для всех стран остаются проблемы создания «безбарьерной» среды для осужденных инвалидов, которая позволит решить определенные проблемы содержания осужденных инвалидов и создаст равные условия при отбывании наказания.

\section{Библиографический список}

1. Постановление Европейского суда по правам человека от 6 февраля 2014 года по делу «Семихвостов против России» (жалоба № 2689/12) // Бюллетень Европейского суда по правам человека. 2014. № 6. С. 13.

2. Басов Н.Ф., Басова В.М., Бобкова Е.Н., Бойцова С.В. Социальная работа с инвалидами: учебное пособие. М.: КноРус, 2012.- 300 с. 
3. Проблемы законодательного обеспечения социальной защиты инвалидов в Российской Федерации/ Аналитический вестник Совета Федерации ФС РФ.-2013.- № 4. С.20-26.

4. Миронова Т.К. Правовое регулирование бесплатного оказания медицинской помощи: учебное пособие. М.: Юстицинформ, 2018. С- 280 с.

5. Синельщикова Е.Ю. Современные аспекты правового регулирования в сфере социальной защиты инвалидов в Российской Федерации // Российская юстиция. 2015. № 3. С. 57-59. 